\title{
KONTRIBUSI KEKUATAN OTOT LENGAN TERHADAP KETERAMPILAN SMASH BOLAVOLI DI SMAN 2 SELUMA
}

\author{
Ajis Sumantri \\ Universitas Dehasen, email: ajissumantri02@gmail.com
}

\begin{abstract}
Abstrak
Penelitian ini bertujuan untuk mengetahui seberapa besar kontribusi kekuatan otot lengan terhadap keterampilan smash dalam permainan bolavoli pada ekstrakurikuler di SMAN 2 Seluma. Metode yang digunakan dalam penelitian ini adalah metode korelasi yaitu teknik analisis korelasi dengan statistik product moment. Populasi dalam penelitian ini berjumlah 45 orang, sampel penelitian ini berjumlah 24 siswa yang diambil dengan teknik purposive sampling. Hasil penelitian ini menunjukkan bahwa siswa ekstrakurikuler SMAN 2 Seluma memiliki tingkat kekuatan otot lengan pada kategori cukup yaitu dengan rata-rata 13,46 dan memiliki tingkat keterampilan smash pada kategori baik yaitu dengan rata-rata 18,33. Kesimpulannya adalah bahwa ada hubungan yang signifikan antara kekuatan otot lengan dengan kemampuan smash siswa ekstrakurikuler bolavoli SMAN 2 Seluma diperoleh thitung $\geq$ ttabel yaitu 7,62 $\geq 2,07$ pada taraf signifikansi $\alpha=0,05(0,5 \%)$. Dengan demikian, $H_{a}$ yang mengatakan terdapat hubungan yang signifikan antara kekuatan otot lengan terhadap keterampilan smash diterima, konsekuensinya $\mathrm{H}_{\mathrm{o}}$ ditolak, dengan kontribusi kekuatan otot lengan terhadap keterampilan smash siswa adalah sebesar $73 \%$.
\end{abstract}

Kata kunci: Kekuatan otot lengan, keterampilan smash

\begin{abstract}
This study aims to determine how much the contribution of arm muscle strength to smash skills in volleyball games in extracurricular activities at SMAN 2 Seluma. The method used in this research is correlation method, which is correlation analysis technique with product moment statistics. The population in this study amounted to 45 people, the sample of this study amounted to 24 students taken by purposive sampling technique. The results of this study indicate that the extracurricular students of SMAN 2 Seluma have arm muscle strength in the moderate category with an average of 13.46 and have a smash skill level in the good category with an average of 18.33. The conclusion is that there is a significant relationship between arm muscle strength and smash ability of the extracurricular students of SMAN 2 Seluma obtained tcount $\geq$ ttable ie $7.62 \geq 2.07$ at the significance level $\alpha=0.05$ (0.5\%). Thus, $H_{a}$ who said there was a significant relationship between arm muscle strength and smash skills was accepted, consequently $H_{0}$ was rejected, with the contribution of arm muscle strength to students' smash skills amounting to $73 \%$.
\end{abstract}

Keywords: Arm muscle strength, smash skills

\section{PENDAHULUAN}

Dalam permainan bolavoli terdiri atas beberapa teknik yaitu servis, passing bawah, passing atas, smash, dan blocking. Smash mempunyai ciri-ciri menukik, tajam, dan cepat. Untuk melakukan smash dengan baik perlu memperhatikan faktorfaktor berikut: awalan, tolakan, pukulan, dan pendaratan. Teknik Smash menurut Iwan Kristianto dalam pjoksmk.blogspot.co m, (2003) "smash adalah pukulan keras yang biasanya mematikan karena bola sulit diterima atau dikembalikan". Sedangkan 
menurut pendapat M. Mariyanto (pjoksmk.blogspot.com, 2006) "smash adalah suatu pukulan yang kuat dimana tangan kontak dengan bola secara penuh pada bagian atas, sehingga jalannya bola terjal dengan kecepatan yang tinggi, apabila pukulan bola lebih tinggi berada di atas net, maka bola dapat dipukul tajam ke bawah". Smash memiliki beberapa jenis antara lain : (1) quick smash, (2) open smash, (3) semi smash. Teknik quick smash digunakan untuk mengembangkan permainan cepat dalam melakukan variasivariasi serangan ke daerah lawan. Open smash dilakukan dengan melambungkan bola cukup tinggi yaitu lebih dari 3 meter diujung net garis samping dengan bola dalam keadaan tenang. Sedangkan semi smash merupakan teknik melakukan smash dengan ketinggian bola $\pm 1-2$ meter di atas net.

Pelaksanaan kegiatan smash meliputi kegiatan : (1) sikap persiapan, (2) sikap menolak (tumpuan), (3) sikap perkenaan bola, dan (4) sikat pendaratan. Dalam permainan bolavoli, kekuatan otot lengan memiliki peran untuk memberikan tenaga sewaktu mengayunkan lengan guna memukul bola yang sekeras-kerasnya. Menurut Beutelstahl (2001: 24) menyatakan bahwa kekuatan otot lengan yang tinggi menyebabkan lengan dapat terjulur kaku dan menyentuh bola guna memukulnya dengan keras. Berdasarkan pengamatan yang telah dilakukan di SMAN 2 Seluma bahwa kemampuan smash belum maksimal, sehingga setiap pertandingan yang diikuti selalu tersisihkan atau belum mendapatkan prestasi. Hal ini dikarenakan dalam latihan tidak memperhatikan kondisi fisik dalam latihan dan kurangnya berlatih secara rutin.

Pada saat melakukan teknik smash tentunya membutuhkan kekuatan otot lengan. Kekuatan otot lengan dapat bekerja secara maksimal apabila tenaga yang dikeluarkan dapat dikontrol dengan baik. Berdasarkan paparan tersebut bahwa kekuatan otot lengan mempunyai kontribusi atau sumbangan yang cukup dominan dalam kemampuan smash. Secara teoritis, faktor penentu kemampuan tersebut dapat dipertanggungjawabkan kebenarannya, namun perlu dibuktikan secara empiris bagaimana sumbangan faktor tersebut terhadap kemampuan smash. Dari uraian diatas maka peneliti ingin mengetahui seberapa besar kontribusi kekuatan otot lengan terhadap keterampilan smash dalam permainan bolavoli pada ekstrakurikuler di SMAN 2 Seluma.

\section{METODE}

Jenis penelitian yang digunakan dalam penelitian ini adalah metode korelasi yaitu teknik analisis korelasi dengan statistik product moment. Populasi dalam penelitian ini adalah siswa ekstrakurikuler SMAN 2 Seluma berjumlah 45 orang. Jenis sampel ini mengunakan teknik tes purposive sampling. Adapun sampel penelitian ini berjumlah 24 siswa, yang terdiri dari 12 siswa laki-laki dan 12 siswa perempuan. Teknik pengumpulan data dilakukan dengan dua tes yaitu tes kekuatan otot lengan yang diwakili oleh tes angkat tubuh dan tes smash pada permainan bolavoli. Kekuatan otot lengan (X) diukur melalui tes push-up. Tes push-up dilakukan sebanyak mungkin tanpa diselingi istirahat. Keterampilan smash (Y) diukur melalui tes melakukan smash. Menurut Nurhasan (2001: 173) petunjuk pelaksanaan smash dilakukan sebaikbaiknya dengan teknik yang benar sebanyak 6 kali data atau point di hitung ketika bola masuk dan mengenai area yang diberikan nomor tetapi ketika bola selama 6 kali pukulan tidak atau hanya mengenai net data tidak dihitung.

Data yang diperoleh dari penelitian ini dilanjutkan dengan menganalisis data kemudian ditarik kesimpulan dengan 
menggunakan statistik parametrik. Adapun teknik analisis data meliputi: (1) Uji normalitas bertujuan untuk mengetahui apakah distribusi datanya menyimpang atau tidak dari distribusi normal, (2) Uji Homogenitas bertujuan untuk menguji kekeliruan eksperimen atau alat eksperimen dan menguji model linier yang telah diambil, (3) Uji korelasi digunakan untuk mengetahui hubungan antara variabel bebas terhadap variabel terikat menggunakan rumus person product moment sebagai berikut :

$r_{x y}=\frac{N \sum X Y\left(\sum X\right)\left(\sum Y\right)}{\sqrt{\left.\left\{N \sum X^{2}-\left(\sum X\right)^{2}\right\} N \sum Y^{2}-\left(\sum Y\right)^{2}\right\}}}$

Keterangan:

$\mathrm{X}=$ Variabel Prediktor

$\mathrm{Y}=$ Variabel Kriterium

$\mathrm{N}=$ Jumlah pasangan skor

$\Sigma x y=$ Jumlah skor kali $x$ dan $y$

$\Sigma \mathrm{x}=$ Jumlah skor $\mathrm{x}$

$\Sigma y=$ Jumlah skor $y$

$\Sigma \times 2$ = Jumlah kuadrat skor $\mathrm{x}$

$\Sigma \mathrm{y} 2$ = Jumlah kuadrat skor $\mathrm{y}$

$(\Sigma x)^{2}=$ Kuadrat jumlah skor $\mathrm{x}$

$(\Sigma y)^{2}=$ Kuadrat jumlah skor $y$

\section{HASIL DAN PEMBAHASAN}

Hasil

Berdasarkan dari hasil tes push up dan tes smash dalam permainan bolavoli pada siswa ekstrakurikuler di SMAN 2 Seluma, maka diperoleh nilai rata-rata, nilai maksimal dan nilai minimal yang diperoleh siswa ekstrakurikuler di SMAN 2 Seluma pada masing-masing tes yang dilakukan. Untuk lebih jelasnya dapat diperhatikan pada tabel dibawah ini :

Tabel 1.Deskripsi Data

\begin{tabular}{|c|c|c|c|c|c|}
\hline & & & & & \\
\hline $\begin{array}{c}\text { Nama } \\
\text { Tes }\end{array}$ & $\begin{array}{c}\text { Jumlah } \\
\text { Hasil } \\
\text { Tes }\end{array}$ & $\begin{array}{l}\text { Nilai } \\
\text { Terti } \\
\text { nggi }\end{array}$ & $\begin{array}{c}\text { Nila } \\
\text { i } \\
\text { Ter } \\
\text { end } \\
\text { ah }\end{array}$ & $\begin{array}{c}\text { Nil } \\
\text { ai } \\
\text { Rat } \\
\text { a- } \\
\text { rat } \\
\text { at }\end{array}$ & $\begin{array}{c}\text { Norma } \\
\text { Penilaia } \\
n\end{array}$ \\
\hline
\end{tabular}

\begin{tabular}{c|c|c|c|c|c}
\hline $\begin{array}{c}\text { Push } \\
\text { Up }\end{array}$ & 323 & 21 & 28 & $\begin{array}{c}13, \\
46\end{array}$ & Cukup \\
\hline $\begin{array}{c}\text { Keter } \\
\text { ampil } \\
\text { an } \\
\begin{array}{c}\text { Smas } \\
h\end{array}\end{array}$ & 440 & 4 & 12 & $\begin{array}{c}18, \\
33\end{array}$ & Baik \\
\hline
\end{tabular}

a. Uji prasyarat data tes push up dan keterampilan smash

1. Uji Normalitas

a) Uji normalitas tes push up siswa ekstrakurikuler di SMAN 2 Seluma. dengan banyak kelas interval rerata $=13,46$

Tabel 2.Perhitungan Normalitas

\begin{tabular}{|c|c|c|c|c|c|c|}
\hline \multicolumn{7}{|c|}{ Data Push Up } \\
\hline No & Interval & Fo & Fh & $\begin{array}{l}\text { (fo- } \\
\text { fh) }\end{array}$ & $\begin{array}{l}\text { (fo- } \\
\text { fh) }\end{array}$ & $\begin{array}{l}\text { (fo- } \\
\text { fh) } \\
\text { fh }\end{array}$ \\
\hline 1 & $19-21$ & 7 & 4 & 3,0 & 9,0 & 2,3 \\
\hline 2 & $16-18$ & 3 & 4 & $-1,0$ & 1,0 & 0,3 \\
\hline 3 & $13-15$ & 4 & 4 & 0,0 & 0,0 & 0,0 \\
\hline 4 & $10-12$ & 4 & 4 & 0,0 & 0,0 & 0,0 \\
\hline 5 & $7-9$ & 0 & 4 & $-4,0$ & 16,0 & 4,0 \\
\hline 6 & $4-6$ & 6 & 4 & 2,0 & 4,0 & 1,0 \\
\hline & Total & 24 & 24 & 0 & 30 & 7,5 \\
\hline
\end{tabular}

b) Uji normalitas tes smash siswa ekstrakurikuler di SMAN 2 Seluma. dengan kelas interval rerata 18,33

Tabel 3. Perhitungan Normalitas Data Smash

\begin{tabular}{|c|c|c|c|c|c|c|}
\hline No & Interval & Fo & Fh & $\begin{array}{l}\text { (fo- } \\
\text { fh) }\end{array}$ & $\begin{array}{l}\text { (fo- } \\
\text { fh) }\end{array}$ & $\begin{array}{l}\frac{(f o-}{f h)^{2}} \\
\frac{f h}{f h}\end{array}$ \\
\hline 1 & $27-29$ & 1 & 4 & $-3,0$ & 9,0 & 2,3 \\
\hline 2 & $24-26$ & 4 & 4 & 0,0 & 0,0 & 0,0 \\
\hline 3 & $21-23$ & 4 & 4 & 0,0 & 0,0 & 0,0 \\
\hline 4 & $18-20$ & 3 & 4 & $-1,0$ & 1,0 & 0,3 \\
\hline 5 & $15-17$ & 3 & 4 & $-1,0$ & 1,0 & 0,3 \\
\hline 6 & $12-14$ & 9 & 4 & 5,0 & 25,0 & 6,3 \\
\hline \multicolumn{2}{|r|}{ Total } & 24 & 24 & 0 & 36 & 9 \\
\hline
\end{tabular}


2. Uji Homogenitas

Jika Fhitung $\leq$ Ftabel maka data homogen

Jika Fhitung $\geq$ Ftabel maka data tidak homogen

Maka nilai Fhitung 1,34 $\leq$ Ftabel 2,00 homogen

3. Uji Korelasional

Berdasarkan perhitungan data diperoleh nilai rhitung sebesar 0,85 sedangkan rtabel pada $\alpha=5 \%$ dan $\mathrm{dk}=\mathrm{n}-2=24-2=$ 22 adalah 0,432 (pada tabel $r$ ). Untuk mengetahui lebih lanjut keeratan hubungan antara kedua variabel tersebut, Ttabel ( dilampirkan ) pada $\alpha=$ 5\% dengan db 22 adalah 2,07. Dari analisis diatas maka diperoleh bahwa thitung $\geq$ ttabel yaitu $7,62 \geq 2,07$, maka dengan demikian dapat dikatakan bahwa terdapat hubungan erat antara otot lengan dengan keterampilan smash pada siswa ekstrakurikuler di SMAN 2 Seluma.

4. Uji Kontribusi

Untuk mengetahui seberapa besar kontribusi kekuatan otot lengan terhadap keterampilan smash pada siswa ekstrakurikuler SMAN 27 Seluma ditentukan dengan rumus:

$$
\begin{aligned}
& K=r^{2} \times 100 \% \\
& K=0,85^{2} \times 100 \% \\
& K=0,73 \times 100 \% \\
& K=73 \%
\end{aligned}
$$

\section{Pembahasan}

Berdasarkan hasil tes kekuatan otot lengan (Push Up) pada siswa ekstrakurikuler di SMAN 2 Seluma, bahwa kekuatan otot lengan dalam kategori cukup yaitu dengan rata-rata 13,46 dan yang memperoleh norma tes di kategori baik sekali sebanyak 7 orang, berkategori baik sebanyak 3 orang, berkategori cukup sebanyak 4 orang, berkategori kurang sebanyak 4 orang dan yang mendapat nilai berkategori sangat kurang sebanyak 6 orang. Nilai tertinggi adalah 21 dan nilai terendah adalah 4 . kekuatan otot lengan didapat hasil $X^{2}$ adalah 7,5 sedangkan $x^{2}$ tabel 35,415 yang berati distribusi normal. Sedangkan tingkat keterampilan smash siswa ekstrakurikuler di SMAN 2 Seluma memiliki tingkat keterampilan smash pada kategori baik yaitu dengan rata-rata 18,33 dan yang memperoleh norma tes di kategori baik sekali sebanyak 10 orang, berkategori baik sebanyak 4 orang, berkategori cukup sebanyak 10 orang, berkategori kurang sebanyak 0 orang dan yang mendapat nilai berkategori sangat kurang sebanyak 0 orang. Nilai tertinggi adalah 28 dan nilai terendah adalah 12. kekuatan otot lengan didapat hasil $X^{2}$ adalah 9 sedangkan $x^{2}$ tabel 35,415 yang berati distribusi normal dan hasil uji homogenitas mendapatkan hasil Fhitung adalah 1,34 dan Ftabel adalah 2,00. Berarti Fhitung 1,34< dari Ftabel 2,00 maka data distribusi Homogen.

Sedangkan hubungan antara
kekuatan otot lengan terhadap
keterampilan smash bolavoli berdasarkan uji korelasi product moment dengan simpangan antara tes push up dengan keterampilan smash siswa ekstrakurikuler di SMAN 2 Seluma adalah 0,85 pada posisi katagori sangat kuat. Sedangkan nilai ttabel ditentukan berdasarkan tingkat signifikansi $(\alpha)$ adalah $5 \%$ yang digunakan dan derajat kebebasan (d.f = n-2) yang besarnya sampel (n) adalah 24, maka d.f $=24-2=22$ berdasarkan distribusi ttabel diperoleh 2,07 . Keputusan diambil dengan jalan membandingkan nilai thitung dengan ttabel. Jika thitung lebih kecil dari ttabel, maka keputusan menerima hipotesis Ho. dan sebaliknya jika thitung lebih besar dari ttabel maka menolak Ho dan menerima $\mathrm{Ha}$, pada pengujian ini, thitung adalah 7,62 lebih besar dari pada ttabel adalah 2,07 maka keputusan menolak hipotesis nol (Ho) dan menerima hipotesis alternatif (Ha). Maka kesimpulannya adalah terdapat korelasi antara variabel $\mathrm{x}$ dan variabel $\mathrm{y}$. Yaitu terdapat hubungan antara kekuatan 
otot lengan terhadap keterampilan smash bolavoli siswa ekstrakurikuler di SMAN 2 Seluma.

Hipotesis yang diajukan dalam
penelitian ini adalah "Kekuatan Otot Lengan memberikan kontribusi yang berarti terhadap Keterampilan smash bolavoli". Kontribusi dan besarnya korelasi variabel Kekuatan Otot Tungkai (X) terhadap keterampilan Smash bolavoli Siswa Ekstrakurikuler di SMAN 2 Seluma (Y) diuji dengan korelasi sederhana, dan uji keberartian dengan uji-t yakni dengan membandingkan harga $t_{\text {hitung }}$ dengan $t_{\text {tabel }}$. Ho yang diuji dalam hal ini adalah koefisien korelasi Kekuatan Otot Tungkai terhadap keterampilan smash bolavoli signifikan. Kriteria pengujian adalah : tolak Ho : jika Nilai $t_{\text {hitung }}>t_{\text {tabel }}$, sebaliknya terima Ho jika nilai $t_{\text {hitung }}<t_{\text {tabel }}$.

Kontribusi Kekuatan Otot Lengan terhadap keterampilan Smash bolavoli siswa ekstrakurikuler di SMAN 2 Seluma adalah sebesar $73 \%$. Dengan ditemukannya kontribusi yang signifikan dari kekuatan otot lengan terhadap keterampilan smash, maka kekuatan otot lengan dapat dijadikan sebagai alat untuk memprediksi keterampilan smash bolavoli siswa ekstrakurikuler di SMAN 2 Seluma. Hasil penelitian membuktikan bahwa terdapat kontribusi kekuatan otot lengan terhadap keterampilan smash bolavoli pada Siswa ekstrakurikuler di SMAN 2 Seluma adalah sebesar 35\%.

\section{PENUTUP}

\section{Simpulan}

1. Bahwa tingkat kekuatan otot lengan Pada siswa ekstrakurikuler di SMAN 2 Seluma memiliki tingkat kekuatan otot lengan pada kategori cukup yaitu dengan rata-rata 13,46 dan tingkat keterampilan smash Siswa ekstrakurikuler di SMAN 2 Seluma memiliki tingkat keterampilan smash pada kategori baik yaitu dengan ratarata 18,33 .

2. Tingkat kekuatan otot lengan siswa memiliki hubungan dengan hasil keterampilan smash siswa ekstrakurikuler di SMAN 2 Seluma hal ini ditunjukan dengan koefisien korelasi 0,85 berada dikategori sangat kuat. Pada pengujian analisis $t$ diperoleh, thitung adalah 7,62 lebih besar daripada ttabel adalah 2,07, maka keputusan menolak hipotesis alternatif (Ho) dan menerima hipotesis alternatif $(\mathrm{Ha})$. Maka kesimpulannya adalah terdapat korelasi antara varibel $x$ dan variabel $y$, yaitu terdapat hubungan antara tes kekuatan otot lengan dengan hasil keterampilan smash siswa ekstrakurikuler di SMAN 2 Seluma pada kategori sangat kuat.

3. Berdasarkan pada hasil penelitian di atas terdapat kontribusi antara tes Push Up dan keterampilan smash pada siswa ekstrakurikuler di SMAN 2 Seluma, bahwa kekuatan otot lengan memiliki tingkat kontribusi pada smash dalam permainan bolavoli sebesar $73 \%$ yang berarti masih banyak faktor lain yang berkontribusi terhadap keterampilan smash pada permainan bolavoli.

\section{Saran}

1. Bagi peneliti yang ingin melanjutkan penelitian ini agar dapat menjadikan penelitian ini sebagai bahan informasi dan meneliti dengan jumlah populasi atau sampel yang lebih besar serta daerah berbeda.

2. Bagi atlet pada umumnya disarankan dapat meningkatkan latihan otot lengan yang telah terbukti memberikan kontribusi sebesar $73 \%$ terhadap keterampilan smash bolavoli dengan cara melakukan latihan secara sistematis dan berkelanjutan.

3. Bagi pelatih pada umumnya dan khususnya pelatih ekstrakurikuler di SMAN Seluma disarankan untuk melatih 
unsur kekuatan otot lengan dengan keterampilan smash karena dalam permainan bolavoli sangat diperlukan keterampilan smash untuk mencipatakan kemenangan. Dalam mengatasi masalah tersebut, diperlukan adanya usaha dan upaya dari pihak siswa yang bersangkutan dan pelatih.

\section{DAFTAR PUSTAKA}

Arikunto, Suharsimi. 2006. Prosedur Penelitian Suatu Pendekatan Praktek. Jakarta: Rineka Cipta.

Arsil. 2018. Evaluasi Pendidikan Jasmani dan Olahraga. Padang: Wineka Media.

Barlian, Eri. 2016. Metodologi Penelitian Kualitatif \& Kuantitatif. Padang: Sukabina Press.

Beutelstahl, Dieter. 2001. Pengertian Servis Dalam Permainan Bolavoli. Jakarta:Universitas terbuka.

Candrawati, Y., \& Ilahi, B. R. (2018). Evaluasi Program Pembinaan Prestasi Olahraga Bola Voli Pada Smk Negeri Di Kota Bengkulu. Kinestetik, 2(1), 44-48.

Edwan, E., Sutisyana, A., \& Restu llahi, B. (2017). Pengaruh metode latihan plyometric terhadap kemampuan jumping smash bola voli siswa ekstrakurikuler SMPN 1 bermani ilir Kabupaten Kepahiang. Jurnal Kinestetik : Jurnal IImiah Pendidikan Jasmani, 1(1), 67-70. doi: 10.33369/jk.v1i1.3380

Fenanlampir, Albertus dan Muhammad Muhyi Faruq. 2015. Tes \& Pengukuran dalam Olahraga. Yogyakarta: CVANDI OFFSET.

Garciana, M. (2019). Pengaruh Latihan Memukul Bola Gantung Terhadap Kemampuan Jump Service Atlet Putra Club Caroline Kota Lubuklinggau Provinsi Sumatera Selatan. Kinestetik, 3(1), 57-62.
Herianto, H., Yarmani, Y., Sutisyana, A., \& Defliyanto, D. (2018). Analisis kemampuan open spike pada siswa putra ekstrakurikuler bola voli di SMPN 18 Kota Bengkulu. Jurnal Kinestetik : Jurnal IImiah Pendidikan Jasmani, 2(2), 27-33. doi: $10.33369 / j k . v 2 i 2.6713$

Lutan, Rusli dkk. 2000. Dasar-Dasar Kepelatihan. Jakarta: Departemen Pendidikan dan Kebudayaan.

Sajoto, Mohammad. 2016. Pembinaan Kondisi Fisik Dalam Olahraga. Jakarta: Depdikbud.

Saptiani, D., Sugiyanto, S., \& Syafrial, S. (2019). Hubungan kekuatan otot lengan dan koordinasi mata tangan terhadap akurasi servis atas bola voli pada peserta putri ekstrakurikuler di SMAN 2 Seluma. Jurnal Kinestetik : Jurnal IImiah Pendidikan Jasmani, 3(1), 42-50. doi: $10.33369 / j k . v 3 i 1.8810$

Shodiq, A., \& Sugihartono, T. (2019). Pengaruh Latihan Lompat Gawang Dalam Meningkatkan Tinggi Lompatan Spike Pada Permainan Bola Voli Siswa Ekstrakurikuler Di Man 2 Kota Bengkulu. Kinestetik, 3(1), 29-33.

Sugihartono, T., \& Pujianto, D. (2019). Upaya Meningkatkan Kemampuan Servis Atas Melalui Penerapan Latihan Menggunakan Dumbbell Pada Siswa Kelas X Ips 6 Sma Plus Negeri 7 Bengkulu. Kinestetik, 3(1), 125-131.

Sutisyana, A., \& Ilahi, B. R. (2017). Pengaruh Metode Latihan Plyometric Terhadap Kemampuan Jumping Smash Bola Voli Siswa Ekstrakurikuler Smpn 1 Bermani llir Kabupaten Kepahiang. Kinestetik, 1(1). 